\title{
Determining gene response patterns of time series gene expression data using $R$
}

\author{
Kevin L O'kello*, Vinhthuy Phan \\ From UT-KBRIN Bioinformatics Summit 2014 \\ Cadiz, KY, USA. 11-13 April 2014
}

\section{Background}

The rapid advancement of sequencing technologies has not been without challenges. The extensive size of genomes as well as the need to comprehend the vast complexities of genomic information has fostered the need to utilize more robust computational methods and statistical analysis tools. In a gene expression study involving multiple treatments, a time series analysis of differentially expressed genes provides great insights into the replicates. Such information is useful in identifying the potential sources of variation that cannot be easily extrapolated from a generalized experimental approach. It is also essential to be able to group the identified gene expression patterns in order to attain meaningful interpretations.

\section{Materials and methods}

The experiment employs the use of R software to identify gene expression patterns in a dataset involving parathyroid tumor treatments [1]. The treatments were generated in a three day time interval. The $\mathrm{R}$ tool provides important packages that are ideal for gene expression studies and also delivers significant visualization and inference resources [2]. The proposed approach for this analysis consists of two stages. First, the Kruskal-Wallis test is used to identify differentially expressed genes. Second, patterns of differentially expressed genes are determined using the Wilcoxon rank-sum test.

\section{Published: 29 September 2014}

\section{References}

1. Haglund F, Ma R, Huss M, Sulaiman L, Lu M, Nilsson IL, Höög A, Juhlin CC Hartman J, Larsson C: Evidence of a functional estrogen receptor in parathyroid adenomas. J Clin Endocrinol Metab 2012, 97(12):4631-4639.

* Correspondence: kokello@memphis.edu

Bioinformatics Program, University of Memphis, Memphis TN 38152, USA
2. Gentleman RC, Carey VJ, Bates DM, Bolstad B, Dettling M, Dudoit S, Ellis B, Gautier L, Ge Y, Gentry J, Hornik K, Hothorn T, Huber W, lacus S, Irizarry R, Leisch F, Li C, Maechier M, Rossini AJ, Sawitzki G, Smith C, Smyth G, Tierney L, Yang JY, Zhang J: Bioconductor: open software development for computational biology and bioinformatics. Genome Biol 2004, 5(10):R80.

doi:10.1186/1471-2105-15-S10-P24

Cite this article as: O'kello and Phan: Determining gene response patterns of time series gene expression data using R. BMC Bioinformatics 2014 15(Suppl 10):P24.
Submit your next manuscript to BioMed Central and take full advantage of:

- Convenient online submission

- Thorough peer review

- No space constraints or color figure charges

- Immediate publication on acceptance

- Inclusion in PubMed, CAS, Scopus and Google Scholar

- Research which is freely available for redistribution
() Biomed Central 